\title{
Perceptions of Lay Judges About Independence of the Judiciary
}

\begin{abstract}
Lay judges are citizens with particular knowledge of and experience with the judiciary. The findings of a survey among the lay judges of ten judiciaries are examined in this chapter. It is found that the perceptions of lay judges of judicial independence, their own as well as that of the professional judges, are very similar to the perceptions of the professional judges. In addition, lay judges are most positive about their independence, when they participate in judicial panels together with professional judges and when they are taken seriously by the professional judges. For them, these conditions surpass sitting alone as a judge. Although selection effects may play a role, the results indicate that experience as a lay judge leads to a much higher appreciation of judicial independence than that of (highly educated) citizens in general. This in turn indicates that the views of the general public are too negative about judicial independence.
\end{abstract}

Keywords Lay judges · Judicial independence · Survey

This Chapter is joint work with Frank van Tulder Bart Diephuis of the Netherlands Council for the Judiciary. Preliminary results have been presented at the 2018 EGPA conference.

(C) The Author(s) 2021

F. van Dijk, Perceptions of the Independence of Judges in Europe, https://doi.org/10.1007/978-3-030-63143-7_4 


\subsection{Lay Judges and Judicial Independence}

Lay judges are a potentially interesting group when one wants to know more about perceptions of the independence of the judiciary. First of all because they are judges in their own right, and therefore their own independence matters. In the second place, they have hands on experience in the judiciary, yet they have less vested interests in the judiciary than professional judges as their primary tasks lay outside the courts. They do not fall under the court hierarchy for their careers like judges (Schneider 2005). Also, they do not have an interest in the cases they adjudicate like the parties and their lawyers. Lay judges are in a position to be more objective about the judiciary than the professional judges as well as the parties and lawyers. Their perceptions of the independence of the whole system are particularly interesting when they fulfil their tasks together with professional judges. This they generally do.

The number of lay judges amounts to 250,000 in the EU, the UK and Norway. ${ }^{1}$ The latter two countries are included because they participated in the survey discussed below. This number can be compared with 83,500 professional judges. It should be stressed that these figures concern the number of persons. In full time equivalents the number of lay judges is only a small but unknown fraction of this figure. The involvement of lay judges is very unevenly spread across countries. In $68 \%$ of the above judiciaries lay judges play a role. In the judiciaries that make use of lay judges, their numbers per 100,000 inhabitants range from 6 in Italy and 8 in Scotland through 37 in France and 112 in Germany to 174 in Denmark and a staggering 856 in Norway (CEPEJ 2018). According to CEPEJ lay judges are working in all areas of law, and in some countries this is actually the case (Denmark, Norway and, except family cases, Belgium). In other countries the participation is much more limited, such as in Scotland where only misdemeanour and minor criminal cases are handled by lay judges. Involvement in serious criminal cases occurs often: in $75 \%$ of the countries that have lay judges. Also, in specific areas of civil law such as labour law there is relatively often involvement of lay judges. Machura (2016) looks at the involvement of lay judges in civil proceedings. He concludes that a wide variety exists in the way lay judges are involved. See

${ }^{1}$ CEPEJ (2018, Table 3.6, p. 109). Data on lay judges for Greece were provided by the Supreme Judicial Council of Greece. Same sources for the other data on numbers of (lay) judges. 
also Burgess et al. (2014) on lay person involvement in specialized labour courts that exist in some countries. Again, differences among countries are large.

The reach of the survey among lay judges of the ENCJ (see Table 3.1) is much smaller than that of the survey among professional judges, because, obviously, not all judiciaries deploy lay judges but also for administrative reasons such as difficulties in reaching lay judges. Ten Judiciaries participated in the survey. Scandinavia had a heavy presence in the survey, but all parts of Europe are represented. As background information, the survey shows how lay judges are deployed. Consistent with the discussion above, the dominant form of lay participation is lay judges taking part in mixed panels with professional judges adjudicating criminal cases, but a variety of settings occurs. See Table 4.1. Only in the UK and Italy lay judges sit without professional judges as dominant form. Some lay judges (approximately 6\%) operate in several settings. On average across countries, $71 \%$ of all settings in which lay judges operate involves interaction with professional judges. In Italy and in the UK this percentage is

Table 4.1 Setting in which lay judges adjudicate cases: number of answers given by type of setting, as percentage of total answers

\begin{tabular}{lllllll}
\hline & $\begin{array}{l}\text { Number of } \\
\text { respondents }\end{array}$ & $\begin{array}{l}\text { Number } \\
\text { of } \\
\text { answers }\end{array}$ & $\begin{array}{l}\text { Alone } \\
(\%)\end{array}$ & $\begin{array}{l}\text { Together } \\
\text { with other } \\
\text { lay judges } \\
\text { only (\%) }\end{array}$ & $\begin{array}{l}\text { Together } \\
\text { with } \\
\text { professional } \\
\text { judges only } \\
(\%)\end{array}$ & $\begin{array}{l}\text { Together } \\
\text { with } \\
\text { professional } \\
\text { judges and } \\
\text { lay judges } \\
(\%)\end{array}$ \\
\hline Belgium & 805 & 918 & 12.6 & 2,0 & 4.9 & 80.5 \\
Denmark & 5,983 & 6,206 & 0.1 & 5.3 & 2.2 & 92.4 \\
Greece & 363 & 366 & 1.4 & 14.2 & 1.4 & 83.1 \\
Italy & 485 & 549 & 68.5 & 1.5 & 15.8 & 14.2 \\
Norway & 7,942 & 8,256 & 0.6 & 10.2 & 3.5 & 85.7 \\
Poland & 763 & 770 & 1.2 & 1.4 & 3.5 & 93.9 \\
$\begin{array}{l}\text { Slovenia } \\
\text { Sweden }\end{array}$ & 429 & 431 & 1.4 & 4.6 & 2.8 & 91.2 \\
UK: E\&W & 2,611 & 2,733 & 0.3 & 2.7 & 2.6 & 94.4 \\
UK: Scotland & 1,106 & 1,415 & 10.8 & 47.6 & 4.5 & 37.1 \\
Total/Average & 20,605 & 21,766 & 14.5 & 9.3 & 4.8 & 71.8 \\
across & & 122 & 48.4 & 3.3 & 6.6 & \\
countries & & & & & & \\
\hline
\end{tabular}

Note Lay judges sometimes operate in several settings, and more than one answer is possible 
much lower: $30 \%$ in Italy, $42 \%$ in England and Wales and $48 \%$ in Scotland. Still, in all countries many lay judges have direct experience with the way professional judges behave which is necessary for the purpose of evaluating the independence of the judiciary as a whole.

In the remainder of this Chapter the following topics will be discussed.

- The perceptions of lay judges of their own independence and of the independence of the professional judges. Perceptions are compared with those of the general public.

- Aspects of independence and the connection of these aspects with the overall perception of independence. The analysis focuses on the interaction of lay judges and professional judges in mixed panels. This interaction is informative about the attitudes of professional judges that in turn affect the independence of lay judges and their perceptions about the independence of professional judges.

- Comparison of the perceptions of lay judges with the perceptions of professional judges.

Table 4.2 provides the summary data. Like the professional judges, the lay judges in the judiciaries that took part in the survey are generally positive about their independence. The survey asked lay judges to rate their own independence as well as the independence of all the lay judges in their country. $^{2}$ The mean score on own independence over the 10 judiciaries was 9.0 on the 11 -points scale from 0 to 10 (average across countries). $59 \%$ of the respondents gave their independence the maximum score of 10 and $21 \%$ a score of 9 . Only $4 \%$ gave a score lower than 6 . Independence of the lay judges in general is less personal as well as broader, as respondents may take aspects such as the selection of lay judges into account. The mean score was lower, 8.5 with $37 \%$ of the respondents awarding a score of 10 and $26 \%$ of $9.5 \%$ gave a score lower than 6 . Examining the outcomes per country, the mean scores on own independence range from 8.7 in Italy to 9.4 in Scotland and on the independence of all lay judges from 7.5 in Italy to 9.3 in Scotland. The outcomes are very similar to the outcomes of the survey among professional judges for these countries.

${ }^{2}$ Literally: "On a scale of 0-10 (where 0 means "not independent at all" and 10 means "highest possible degree of independence") as a judge I am". Same, but: "the lay judges in my country are". 
Table 4.2 Summary statistics of the perceptions of judicial independence of lay judges by lay judges (personally and all lay judges) and professional judges by lay judges, the perceptions of independence of professional judges (personal and general) by professional judges and the perceptions of independence by the general public, for 10 judiciaries

\begin{tabular}{|c|c|c|c|c|c|c|c|}
\hline & $\begin{array}{l}\text { Lay judges } \\
\text { own }\end{array}$ & $\begin{array}{l}\text { Lay } \\
\text { judges } \\
\text { all }\end{array}$ & $\begin{array}{l}\text { Lay } \\
\text { judges } \\
\text { on prof. } \\
\text { judges }\end{array}$ & $\begin{array}{l}\text { Professional } \\
\text { judges own }\end{array}$ & $\begin{array}{l}\text { Professional } \\
\text { judges all }\end{array}$ & $\begin{array}{l}\text { General } \\
\text { public }\end{array}$ & $\begin{array}{l}\text { General } \\
\text { public } \\
e d u+\end{array}$ \\
\hline Mean & 9.0 & 8.5 & 8.5 & 9.1 & 8.7 & 5.9 & 6.2 \\
\hline Min-Max & $8.7-9.4$ & $7.5-9.3$ & $7.4-9.3$ & $8.4-9.8$ & $7.6-9.8$ & $4.3-8.0$ & $4.1-8.2$ \\
\hline SD & 0.3 & 0.6 & 0.7 & 0.4 & 0.8 & 1.3 & 1.6 \\
\hline \multicolumn{8}{|c|}{ Typical patterns } \\
\hline Greece & 8.9 & 8.1 & 7.4 & 8.9 & 8.0 & 5.6 & 5.5 \\
\hline Italy & 8.7 & 7.5 & 7.8 & 9.3 & 8.4 & 4.4 & 4.8 \\
\hline Sweden & 9.3 & 8.6 & 8.9 & 9.1 & 8.6 & 7.3 & 7.7 \\
\hline \multicolumn{8}{|c|}{ Correlations } \\
\hline $\begin{array}{l}\text { Lay } \\
\text { judges } \\
\text { own }\end{array}$ & 1 & $0.89^{* *}$ & $0.84^{* *}$ & $0.69^{*}$ & $0.76^{*}$ & $0.90^{* *}$ & $0.94^{* *}$ \\
\hline $\begin{array}{l}\text { Lay } \\
\text { judges all }\end{array}$ & & 1 & 0.90 ** & 0.63 & $0.83^{* *}$ & $0.84^{* *}$ & 0.90 ** \\
\hline $\begin{array}{l}\text { Lay } \\
\text { judges } \\
\text { on prof. }\end{array}$ & & & 1 & $0.70^{*}$ & $0.86^{* *}$ & $0.83^{* *}$ & $0.90^{* *}$ \\
\hline $\begin{array}{l}\text { Prof. } \\
\text { judges } \\
\text { own }\end{array}$ & & & & 1 & 0.91 ** & $0.79^{*}$ & $0.81^{* *}$ \\
\hline $\begin{array}{l}\text { Prof. } \\
\text { judges all }\end{array}$ & & & & & 1 & $0.82^{* *}$ & $0.89^{* *}$ \\
\hline $\begin{array}{l}\text { General } \\
\text { public }\end{array}$ & & & & & & 1 & $0.97^{* *}$ \\
\hline $\begin{array}{l}\text { General } \\
\text { public } \\
\text { edu+ }\end{array}$ & & & & & & & 1 \\
\hline
\end{tabular}

\section{Notes}

1. BE, DK, EL, IT, NO, PL, SL, SW, UK EW, and UK SC

2. Correlation across countries. Significance: ${ }^{* *} 0.01$ and ${ }^{*} 0.05$. See list of country abbreviations at the end of Chapter 3

3. Poland: scores for professional judges based on ENCJ survey 2017

4. $N=10$ for all except general public; $N=9$ for general public (no data for Norway)

5. Paired sample $T$-test of means on country level: the means do not differ (at $5 \%$ significance level) of: (1) lay judges all and lay judges on professional judges, (2) Lay judges own and professional judges own, lay judges all and professional judges all, and lay judges on professional judges and professional judges all 
The lay judges were also asked to rate the independence of the professional judges in their country. The scores are nearly the same as those for the lay judges themselves: the mean score was 8.5 with $39 \%$ of the respondents awarding a score of 10 and $25 \%$ of $9.6 \%$ gave a score lower than 6 . Examining the outcomes per country, the means range from 7.4 in Greece and Poland to 9.3 in Denmark. Across country correlations are high between all measures, except the personal independence scores of the professional judges, which we saw earlier as well. The first conclusion is that lay judges and professional judges have very similar views on actual independence. This extreme similarity is surprising.

The last two columns of Table 4.2 give the perceptions of the general public, overall and with a high level of education. While correlations are high, the large difference in level with the professional judges is repeated here for the lay judges. The second conclusion is, therefore, that lay judges are in the mean much more positive about the independence of the judiciary than the public in general, whether it concerns their personal independence, the independence of all lay judges or that of the professional judges. It might be assumed that lay judges are generally recruited from citizens with a higher education. The last column of Table 4.2 gives the outcomes for the part of the general public that has a high education. The impact of education is small for the countries that participated in the surveys. High education reduces the differences only a little, but increases the correlations, as would be expected.

These findings suggest that direct observation and participation in the adjudication of cases lead to higher appreciation of the work of judges. This presupposes that the opinions that the persons held before they became lay judges were similar to those of the (highly educated) general public. Alternative or complementary explanations cannot be ruled out. Cultural adaptation to the dominant professional judges, combined with lack of understanding what really goes on during trials, cannot be excluded as cause for positive perceptions. These findings show, however, similarity with the outcomes of research into the perceptions of citizens about the evaluation of evidence and the severity of sentences in criminal cases in the Netherlands: once citizens had to decide on sentences themselves with knowledge of the facts of the case, the initial view that actual sentences were too lenient disappeared, and the opinions of judges and citizens converged (Wagenaar 2008). In both situations the opinions of judges and citizens converge, while in the latter citizens and judges did not interact. Members of the public are apparently so unfamiliar with the 
judiciary that a large shift in opinions is possible, once the knowledge gap has been filled.

\subsection{INTERACTION OF LAY JUDGES ANd Professional Judges}

The independence of lay judges is not entirely the same as that of professional judges. Lay judges have to relate with the professional judges, in particular when they participate in mixed teams, and they may heavily depend on them. An analysis of the independence of lay judges, therefore, needs to consider the interaction of lay and professional judges in mixed panels, as the dominant form of interaction.

An important issue in the literature about lay judges is whether lay judges have influence on decisions, when participating in mixed panels. Casper and Zeisel concluded in 1972 in an impressive, in depth study that "the traceable overall effect of the lay judges on the verdicts of the German criminal courts is indeed small" (Casper and Zeisel 1972, p. 189). The study finds that lay judges affect the verdict in only $1.4 \%$ of all cases. It notes that it is not known "whether lay judges feel encouraged or restrained in the performance of their duty by the professional judges that sit with them" (Casper and Zeisel 1972, p. 189). A similar view about the limited impact of lay judges in mixed teams is expressed for Sweden in Diesen (2001). The same conclusion is reached in Kutnjak Ivkovic $(2003,2007)$ about the impact of lay judges on the (quality of) decisions and their active participation in deliberations, but there other beneficial, social aspects are stressed, leading to a positive evaluation of mixed panels. Voigt $(2009$, p. 327$)$ finds that "the effects of lay participation on the judicial system, a number of governance variables but also on economic performance indicators are rather modest." These findings raise the question whether the professional judges bolster the independence of lay judges or detract from their independence.

The survey among the lay judges allows an answer to this question from the perspective of the lay judges themselves. Using the survey data, an analysis of the factors that affect their perception of independence can be made. Table 4.3 presents the results of a regression analysis at the individual level. The dependent variable is the perceived independence of lay judges in general, and the independent variables are personal characteristics, perceived external and internal pressure and the interaction with professional judges. All variables prove to play a significant role. Here, it 
Table 4.3 Determinants of perceived independence of lay judges, linear regression

\begin{tabular}{|c|c|c|c|}
\hline \multirow[b]{2}{*}{ Variable } & \multicolumn{3}{|c|}{$\begin{array}{l}\text { Perceived independence of lay } \\
\text { judges }\end{array}$} \\
\hline & Variant 1 & Variant 2 & Variation \\
\hline Inappropriate pressure & $0.46 * * *$ & $0.30 * * *$ & 0.21 \\
\hline Accepted bribes & $0.21 * * *$ & $0.17 * * *$ & 0.10 \\
\hline $\begin{array}{l}\text { Affected by a threat or an actual disciplinary or } \\
\text { other action }\end{array}$ & $0.24 * * *$ & $0.21 * * *$ & 0.09 \\
\hline Decisions affected by actions of the media & $0.18 * * *$ & $0.12 * * *$ & 0.11 \\
\hline Decisions affected by actions using social media & $0.14 * * *$ & $0.13 * * *$ & 0.12 \\
\hline Gender $(0=$ male, $1=$ female $)$ & & $-0.12 * * *$ & 0.06 \\
\hline Age (years) & & $0.01 * * *$ & 0.13 \\
\hline Number of cases & & 0.02 & 0.03 \\
\hline Resolved cases alone & & 0.04 & 0.01 \\
\hline Resolved cases together with professional judges & & $0.14 * * *$ & 0.04 \\
\hline $\begin{array}{l}\text { Inappropriate influence of professionals in mixed } \\
\text { panel }\end{array}$ & & $0.16^{* * *}$ & 0.15 \\
\hline $\begin{array}{l}\text { Contribution taken seriously by professionals in } \\
\text { mixed panel }\end{array}$ & & $0.29 * * *$ & 0.24 \\
\hline Had impact on decision in mixed panel & & $0.17 * * *$ & 0.16 \\
\hline Dummy per country is included & yes & yes & \\
\hline$R$ & 0.17 & 0.22 & \\
\hline$N$ & 20,605 & 18,996 & \\
\hline
\end{tabular}

Notes

1. Significance levels: ${ }^{*} 0.05,{ }^{* *} 0.01$ and ${ }^{* * *} 0.01$

2. All variables, accept for individual characteristics, concern lay judges in general. For all variables higher, is better

3. Two variants: variant 1 includes only aspects of independence that are relevant for lay judges as well as professional judges; variant 2 is the full model

4. Last column gives an indication of the variation in perceived independence that can be attributed to the related variable in variant 2 . In this measure the absolute effect (given in the former column) and the standard deviation of the variable in the survey are combined

is of particular interest that the survey not only includes questions about the setting in which lay judges adjudicate cases, but also contains questions about the quality of the interaction when they sit together with professional judges. While one would expect that lay judges feel most independent when they sit alone, the outcomes show otherwise. Lay judges feel most independent when they sit with professional judges and they are respected by these professional judges in the sense that (1) they 
experience no inappropriate influence of these judges, (2) their contributions are taken seriously by them and (3) they have an impact on decisions. These conditions are according to the survey generally met: on average across countries, respectively, 84,88 and $75 \%$ of the respondents (strongly) agree with the statements about these three aspects. As a result, lay judges operating in mixed panels perceive on average the independence of lay judges in their country approximately 0.14 points higher than their colleagues sitting with only other lay judges and approx. 0.10 points higher than lay judges sitting alone. However, if lay judges score neutral or negative on all three of the items about the functioning of mixed panels, their perception of the independence of lay judges in the country is at least 0.75 points lower than that of their colleagues not sitting in mixed panels. Practically, this is not relevant, as only $1 \%$ of the responding lay judges in mixed panels are neutral or negative about all three aspects.

To conclude, most lay judges interact with professional judges in mixed teams, they experience this generally as positive, and they derive from this a positive perception about their independence. These outcomes are very different from the conclusions of the literature that we discussed. The difference may be caused by the countries that participated. For instance, Germany, the country studied by Casper and Zeisel (1972), did not participate in the survey. Apart from timeframe, the big difference is, however, the methodology, as here the survey among lay judges provides the data, while the study of Casper and Zeisel (1972) is based on a relatively small survey among professional judges. As the perceptions of lay judges themselves are the subject of this Chapter, the differences in outcome do not detract from the relevance of the survey in this context, but point to the need for more research in this rather neglected area.

\subsection{What Do Lay Judges Think About Professional Judges?}

As Table 4.2 shows, in the mean across countries there is no difference between the views of professional judges and lay judges about the independence of professional judges. At the national level, the means of judges and lay judges differ significantly when evaluated at the individual level. ${ }^{3}$

${ }^{3}$ T-test at individual level. Significance level: $0.1 \%$, except Belgium $1 \%$ and Poland $5 \%$. 
Combining the data for England and Wales and Scotland, in 6 out of 9 countries lay judges are less positive about the independence of professional judges than the professional judges themselves. For instance, in Italy lay judges are more critical $(7.8$ vs 8.4$)$ as well as in Greece (7.4 vs 8.0 ). The opposite occurs in three countries (Belgium, Slovenia and Sweden). For Slovenia the difference is substantial (7.6 vs 8.2). Even in countries where lay judges are more critical than professional judges about the independence of professional judges, their assessment is much closer to that of the professional judges than to that of the general public, educated or not. Also, in the view of the lay judges, the interaction between lay and professional judges is in general positive. It seems safe to conclude that there is no disconnect between judges and lay judges in the countries for which data are available. Although alternative explanations such as dominance of the professional judges who set the standards of behaviour that are uncritically followed by the lay judges cannot be ruled out, the gap between judges and citizens disappears, once citizens experience hands-on how judges work, and do the work themselves. If this is so, the general public is not well informed about the judiciary, and their perceptions of judicial independence are distorted. At the same time, lay judges are not able to bring the perception of the general public about independence in line with their own perceptions to the extent that the gap is closed between their perceptions and those of the general public.

\section{REFERENCES}

Burgess, P., S. Corby, and P.L. Latreille. 2014. Lay judges and labor courts: A question of legitimacy. Comparative Labor Law and Policy Journal 35: 191-215.

Casper, G., and H. Zeisel. 1972. Lay judges in the German criminal courts. The Journal of Legal Studies 1 (1): 135-191.

CEPEJ. 2018. European judicial systems: Efficiency and quality. CEPEJ Studies No 23.

Diesen, C. 2001. The advantages and disadvantages of lay judges from a Swedish perspective. Revue internationale de droit penal 72: 355-363.

ENCJ. 2017. Independence, accountability and quality of the judiciary: Performance indicators 2017. ENCJ Report 2016-2017. www.encj.eu.

ENCJ. 2018. Data ENCJ Survey on the independence of lay judges 2017-2018. www.encj.eu.

Kutnjak Ivkovic, S. 2003. An inside view: Professional judges' and lay judges support for mixed tribunals. Law \& Policy 25: 93-122. 
Kutnjak Ivkovic, S. 2007. Exploring lay participation in legal decision-making: Lessons from mixed tribunals. Cornell International Law Journal 40: 429453.

Machura, S. 2016. Civil justice: Lay judges in the EU countries. Onati SocioLegal Series 6 (2): 235-254.

Schneider, M.R. 2005. Judicial career incentives and court performance: An empirical study of the German labour courts of appeal. European Journal of Law and Economics 20: 127-144.

Voigt, S. 2009. The effects of lay participation in courts; A cross country analysis. European Journal of Political Economy 25: 327-339.

Wagenaar, A. 2008. Strafrechtelijke oordelen van rechters en leken: bewijsbeslissingen, straffen en hun argumentatie. Research memoranda 2/4. Netherlands Council for the Judiciary.

Open Access This chapter is licensed under the terms of the Creative Commons Attribution 4.0 International License (http://creativecommons.org/licenses/ by $/ 4.0 /)$, which permits use, sharing, adaptation, distribution and reproduction in any medium or format, as long as you give appropriate credit to the original author(s) and the source, provide a link to the Creative Commons license and indicate if changes were made.

The images or other third party material in this chapter are included in the chapter's Creative Commons license, unless indicated otherwise in a credit line to the material. If material is not included in the chapter's Creative Commons license and your intended use is not permitted by statutory regulation or exceeds the permitted use, you will need to obtain permission directly from the copyright holder.

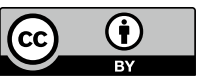

